\title{
SOME OBSERVATIONS ON REPRODUCTION IN THE FEMALE AGOUTI, DASYPROCTA AGUTI
}

\author{
BARBARA J. WEIR \\ Wellcome Institute of Comparative Physiology, \\ The Zoological Society of London, Regent's Park, London, $\mathcal{N} . W .1$
}

(Received 19th March 1970)

\begin{abstract}
Summary. Agoutis (Dasyprocta aguti) were investigated in the laboratory for comparison of their reproductive characteristics with those of other hystricomorphs. A vaginal closure membrane was present and the length of the oestrous cycle averaged $34 \cdot 2 \pm 2 \cdot 1$ days. The ovaries and reproductive tracts of these animals, together with specimens obtained post mortem were studied and some correlations with physiological condition attempted. The ovary of the agouti is characterized by the presence of large numbers of accessory corpora lutea and by the extensive interstitial tissue which appears to replace completely the stroma of other mammals. Patches of 'immature testis tubules' were found in the ovaries of several animals.
\end{abstract}

\section{INTRODUCTION}

Like the acouchi (see Weir, 1971), the agouti is a dasyproctid member of the rodent sub-order Hystricomorpha. It is a large animal weighing 2 to $4 \mathrm{~kg}$ when adult and its natural habitat is the tropical and subtropical areas of northern South America (Cabrera \& Yepes, 1960). It is rarely seen during the day (Enders, 1931) but may be common in areas unmolested by man. Laboratory studies on Dasyprocta have been few: placentation was studied by Strahl (1905) and Becher (1921a, b), and behaviour by Roth-Kolar (1957). Agoutis do not breed readily in captivity (Crandall, 1944) and the first reference to agoutis kept in the laboratory was by Weir (1967a, b). The length of gestation has been reported as 44 days by Enders (1931), 104 days by Brown (1936) and about 105 days by Roth-Kolar (1957). These figures have not been confirmed, but it is reasonable to assume that gestation probably lasts more than 100 days, as in most hystricomorphs except the Caviidae (Rood \& Weir, 1970).

The pattern of reproductive physiology in the agouti is of interest for comparison with that of other hystricomorphs (e.g. guinea-pig: Asdell, 1964; Marshall, 1952-66; chinchilla: Weir, 1966, 1967b; coypu: Newson, 1966; Rowlands \& Heap, 1966; acouchi: Weir, 1971). This paper is a report on the material collected from agoutis in this laboratory during the last $5 \frac{1}{2}$ years.

\section{MATERIALS AND METHODS}

The animals used in the present study are listed in Table 1 . They were obtained from two sources. The laboratory agoutis were housed and handled as described 
by Weir (1967a) and Lemmon \& Weir (1968). They were examined daily for reproductive condition and then killed at known stages of the reproductive cycle. The length of an oestrous cycle was determined as the interval from the 1st day of vaginal opening in one cycle up to, but not including, the 1st day of opening in the next cycle.

One of the laboratory females (D 9) was received when immature and did not exhibit vaginal opening during the next 2 years. Following a single intraperitoneal injection of 200 i.u. pregnant mares' serum gonadotrophin (PMSG) and one of 50 i.u. human chorionic gonadotrophin (HGG) $72 \mathrm{hr}$ later, this female was killed $72 \mathrm{hr}$ after the HCG injection.

TABLE 1

SOURGES AND OBSERVATIONS OF AGOUTIS USED FOR THIS STUDY

\begin{tabular}{|c|c|c|c|c|c|c|c|c|c|}
\hline \multirow{2}{*}{$\begin{array}{c}\text { Animal } \\
\text { no. } \\
(D)\end{array}$} & \multirow{2}{*}{$\begin{array}{c}\text { Body } \\
w t \\
(k g)\end{array}$} & \multirow{2}{*}{ Source } & \multirow{2}{*}{$\begin{array}{c}\text { Cause of } \\
\text { death }\end{array}$} & \multicolumn{3}{|c|}{$\begin{array}{l}\text { Histological } \\
\text { observations }\end{array}$} & \multirow{2}{*}{$\begin{array}{l}\text { Reproductive } \\
\text { state }\end{array}$} & \multicolumn{2}{|c|}{$\begin{array}{l}\text { No. of } \\
\text { eggs or } \\
\text { embryos }\end{array}$} \\
\hline & & & & Ovaries & Uterus & Vagina & & Left & Right \\
\hline 2 & $3 \cdot 50$ & Laboratory & Killed & ++ & + & + & Pro-oestrous & - & - \\
\hline 3 & $3 \cdot 21$ & Laboratory & Killed & ++ & + & - & Post-oestrous & 一 & - \\
\hline 4 & $4 \cdot 10$ & Laboratory & Killed & ++ & - & - & Mid-cycle & - & - \\
\hline 6 & $3 \cdot 20$ & Laboratory & Killed & ++ & + & + & Pro-oestrous & - & - \\
\hline 8 & $2 \cdot 70$ & Laboratory & Killed & ++ & + & + & $\begin{array}{l}\text { Post-ovulation, } \\
\text { but no vaginal } \\
\text { opening }\end{array}$ & - & - \\
\hline 9 & $4 \cdot 20$ & Laboratory & Killed & ++ & + & + & $\begin{array}{l}\text { Experimental in- } \\
\text { duction of ovula- }\end{array}$ & 2 & 3 \\
\hline 10 & $3 \cdot 50$ & ZSL & Unknown & ++ & - & - & Pregnant but & 0 & 2 \\
\hline 13 & $2 \cdot 80$ & ZSL & Infection & -+ & - & + & Immature & - & - \\
\hline 14 & $3 \cdot 17$ & $\mathrm{ZSL}$ & Unknown & ++ & - & + & Mid-cycle & - & - \\
\hline 15 & $3 \cdot 68$ & ZSL & Unknown & ++ & - & - & Mid-cycle & 一 & - \\
\hline 16 & $3 \cdot 14$ & $\mathrm{ZSL}$ & Unknown & $+t$ & + & + & Post-oestrous & - & - \\
\hline 17 & $3 \cdot 5$ & ZSL & Unknown & ++ & & 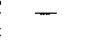 & $\begin{array}{l}\text { Pregnant but re- } \\
\text { sorbing }\end{array}$ & 0 & 2 \\
\hline 18 & $3 \cdot 52$ & ZSL & Unknown & ++ & + & + & Post-partum & 0 & 2 \\
\hline 19 & $3 \cdot 03$ & ZSL & Unknown & ++ & + & + & ? Undecided & - & - \\
\hline 20 & 3.55 & ZSL & Dystocia & ++ & - & - & Pregnant at term & 0 & 1 \\
\hline
\end{tabular}

+ , Studied; -, not available for study, ZSL—Zoological Society of London post-mortem room.

The remaining animals were obtained post mortem from the Zoological Society of London and in most cases the reproductive history was unknown.

The ovaries and reproductive tract were examined macroscopically and fixed in Bouin's fluid. Representative sections were cut at $4 \mu$ of all tissues, except ovaries which were serially sectioned at $5 \mu$ and every fifth or tenth section was mounted. If ovulation had occurred, the corresponding Fallopian tube was similarly treated.

The routine stains used were Mayer's haemalum and eosin, Heidenhain's azan and periodic-acid-Schiff.

Standard statistical methods were applied and all values expressed as means \pm the standard error of the mean. 


\section{RESULTS}

\section{OBSERVATIONS ON LIVING ANIMALS}

Agoutis, like most other hystricomorphs, have a vaginal closure membrane which becomes perforate for 1 to 10 days at oestrus. The mean length of twenty-nine oestrous cycles in three animals was $34 \cdot 2 \pm 2 \cdot 1$ days. The individual means were $27 \cdot 5 \pm 3 \cdot 4$ days $(\mathrm{N}=12), 37 \cdot 6 \pm 2 \cdot 0$ days $(\mathrm{N}=11)$ and $41 \cdot 3 \pm 4 \cdot 4$ days $(\mathrm{N}=6)$. The mean length of six other cycles in the summer months was $87 \cdot 2 \pm 9 \cdot 8$ days, which was significantly longer $(P<0.001)$ than that of cycles at other times, and may indicate that the agouti has an annual anoestrous period.

The vagina of $\mathrm{D} 9$ remained imperforate after treatment with gonadotrophins.

Under laboratory conditions of captivity (Weir, 1967a), copulation occurred only once but conception did not follow and no gestation lengths were determined.

\section{MACROSCOPIG ANATOMY}

The ovaries of the agouti are fairly large $(207 \cdot 1 \pm 19 \cdot 3 \mathrm{mg} ; \mathrm{N}=23)$, ovoid bodies lying just by the posterior border of the kidney and supported along their whole length by the mesovarium. The presence of follicles or corpora lutea (CL) can rarely be determined from macroscopic examination of the ovary as these structures are usually deeply situated (see Pl. 1, Fig. 1) and their appearance is masked by the large amounts of interstitial tissue which are present. There is no ovarian bursa, although the mesosalpinx covers part of the ovarian surface. The Fallopian tube has a prominent cranial loop and is less convoluted than it is in some other hystricomorphs, e.g. chinchilla. The uterus is bicornuate and each horn opens separately through the large, solid cervix. The vagina is long and bends sharply ventral to the vulva where the closure membrane is found.

\section{MICROSCOPIC ANATOMY}

Since no description of the female tract of the agouti exists in the literature, the characteristics of each tissue type will be described and collated with physiological events depending on the material available.

\section{Ovary}

An agouti ovary is shown in Pl. 1, Fig. 1. It is composed of the following cell or tissue types: oocytes, follicles, CL, accessory CL, interstitial tissue, connective tissue and a well developed vascular system. These tissues are found in most mammalian ovaries in varying proportions, but the agouti ovary is characterized by abundant amounts of interstitial tissue. 'Immature testis tubules' (Pl. 3, Figs. 11 and 12) have also been found in some ovaries and one animal (D 15) had bilateral papillomata (Pl. 1, Fig. 2).

Oocytes and follicles. Primary oocytes are found in the cortex of the ovary below the tunica albuginea. Antrum development takes place when the follicle is about $200 \mu$ in diameter. The largest normal follicles seen were about $800 \mu$ in 


\section{EXPLANATION OF PLATES}

\section{PLATE 1}

FIG. 1. Section through the ovary of D 18 (post partum). The two cL of pregnancy are deeply situated and there are numerous accessory CL. The remaining parts of the ovary are of interstitial tissue (compare with the dense stroma of the acouchi, Pl. 1, Fig. 1 of Weir, 1971). Bouin, $5 \mu, \mathrm{H} \& \mathrm{E} ; \times 14$.

FIG. 2. Part of the ovary of D 15 which had a bilateral papilloma. The ovarian tissue (below) is normal with accessory $\mathrm{cL}$, small follicles and interstitial tissue. The germinal epithelium has developed into a papilloma (above) with a central core of connective tissue. Bouin, $5 \mu, \mathrm{H} \& \mathrm{E} ; \times 11$.

FIG. 3. Maturing follicle of D 6 (pro-oestrous). Note the wide theca externa and the poorly developed theca interna. Bouin, $5 \mu, \mathrm{H} \& \mathrm{E} ; \times 75$.

\section{PLATE 2}

Fig. 4. Part of a CL of pregnancy of D 18 which died some time after parturition. Little regression in size of the CL had taken place and the luteal cells appear healthy, but endothelial invasion is prominent. Bouin, $5 \mu, \mathrm{H} \& \mathrm{E} ; \times 225$.

Fig. 5. Part of the pregnancy CL of D 17 which was resorbing. The luteal cells are small and the few nuclei are pyknotic. Vacuoles and endothelial infiltration are present. Bouin, $5 \mu, \mathrm{H} \& \mathrm{E} ; \times 225$.

Figs. 6, 7 and 8. These are sections from the three types of CL found in the same ovary of D 16 (post-oestrous) and all were greater than $2 \frac{1}{2} \mathrm{~mm}$ in diameter. Fig. 6 shows the most recently formed CL with large luteal cells and the theca externa still present. Fig. 7 is of an older CL where the boundary is less distinct, vacuoles are present and endothelial cells are proliferating. Fig. 8 shows an old cL with many more and larger vacuoles. Bouin, $5 \mu$, $\mathrm{H} \& \mathrm{E} ; \times 225$.

\section{PLATE 3}

FrG. 9. Part of the left ovary of D 20 (at term) showing the early stages of luteinization of a large ( $1000 \mu$ diameter) follicle. The edge of a previously luteinized follicle can be seen at the left and the remaining cells are interstitial cells. Bouin, $5 \mu, \mathrm{H} \& \mathrm{E} ; \times 128$.

FIG. 10. Part of the right ovary of D 20 (at term) with a cL of pregnancy below and a follicle above. The central cells of the follicle have luteinized; the outer cells have a clear cytoplasm and resemble the interstitial cells outside the follicle. The theca externa of the follicle has been broached and the two sets of interstitial cells are connected. Bouin, $5 \mu$, $\mathrm{H} \& \mathrm{E} ; \times 120$.

Fig. 11. A patch of 'immature testis tubules' in the ovary of D 3 (post-oestrous). Note the interstitial tissue surrounding and between the tubules. Bouin, $5 \mu, \mathrm{H} \& \mathrm{E} ; \times 200$.

FIG. 12. Section through the testis of an immature male agouti for comparison of the testis tubules with those found in the ovaries of some female agoutis. Bouin, $4 \mu, \mathrm{H} \& \mathrm{E} ; \times 200$.

\section{PLATE 4}

Fig. 13. Part of the uterus of $D 2$ (pro-oestrous) showing the shallow endometrium, sparse glands and leucocytosis. Bouin, $4 \mu, \mathrm{H} \& \mathrm{E} ; \times 150$.

FIG. 14. Part of the uterus of $D 3$ (post-oestrous) showing numerous glands and a deep endometrium. Bouin, $4 \mu, \mathrm{H} \& \mathrm{E} ; \times 150$.

FIG. 15. In the uterus of D 19, the endometrium is typically shallow and leucocytosis is apparent but the glands are numerous. Bouin, $4 \mu, \mathrm{H} \& \mathrm{E} ; \times 150$.

FIG. 16. Vaginal wall of D 2 (pro-oestrous) showing extensive mucification. Bouin, $4 \mu$, H \& $\mathrm{E} ; \times 200$.

Fig. 17. Vagina of D 8, which had probably ovulated without concomitant vaginal opening, showing cornification. The remains of the pro-oestrous secretion of mucus can be seen above. Bouin, $4 \mu, \mathrm{H} \& \mathrm{E} ; \times 200$.

Fig. 18. Part of the ovary of $\mathrm{D} 3$ (post-oestrous) showing remnant of a zona pellucida in a mass of interstitial tissue derived from the follicle. Bouin, $5 \mu, \mathrm{H} \& \mathrm{E} ; \times 240$.

FIG. 19. Ovum in the Fallopian tube of $\mathrm{D} 9$ which was treated with exogenous gonadotrophins. Bouin, $5 \mu$, Azan, $\times 320$. 
PLATE 1

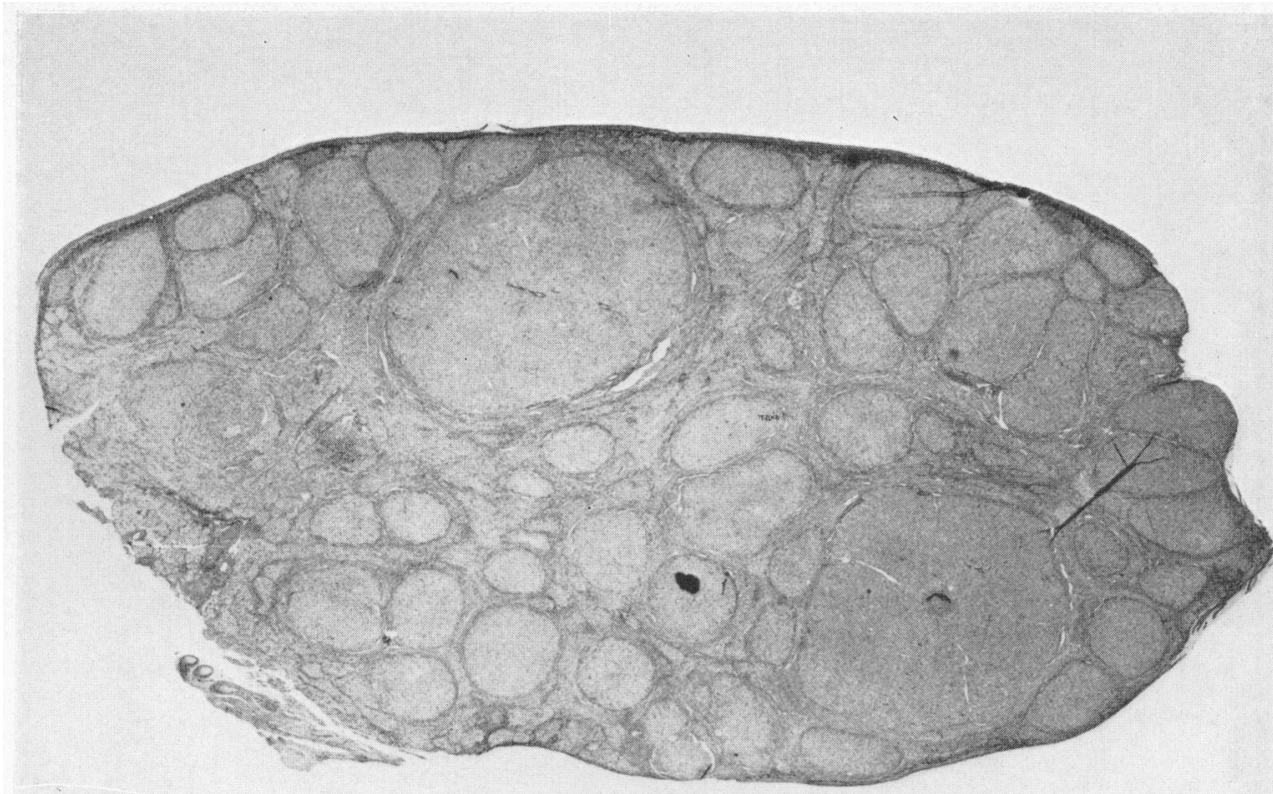

1

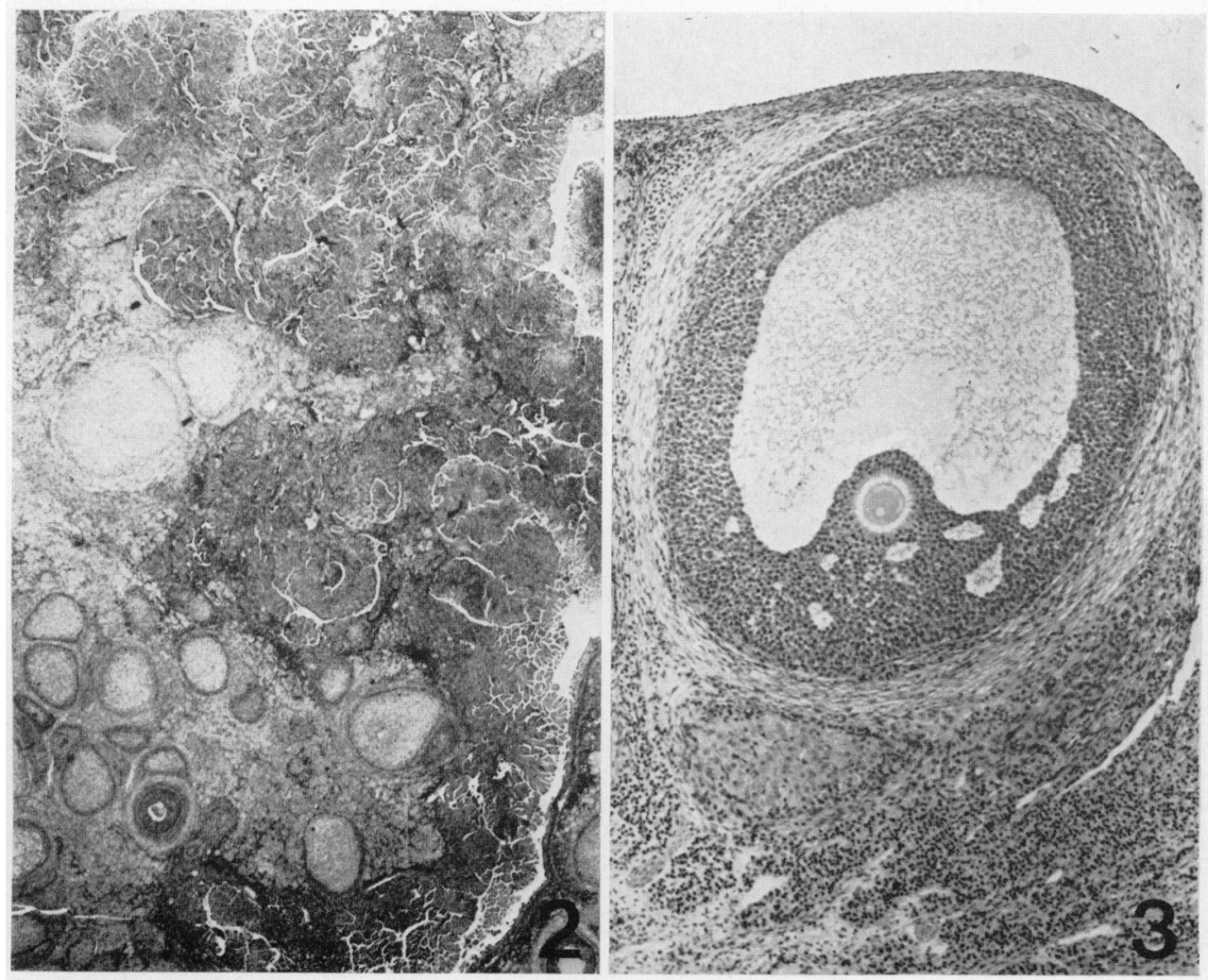

(Facing p. 206) 


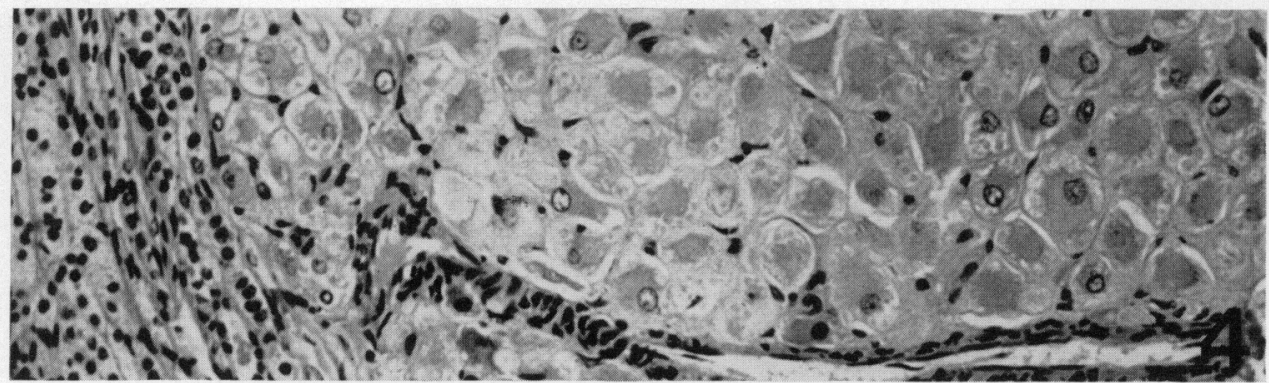

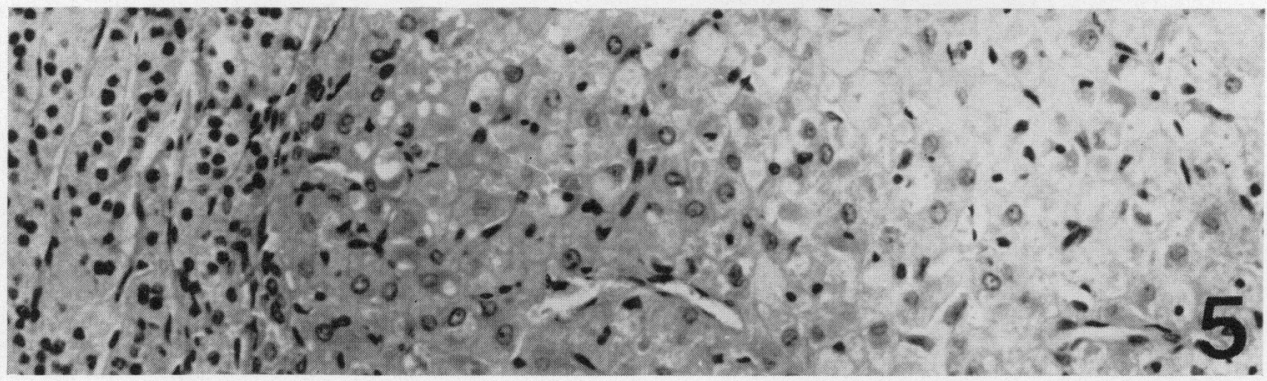

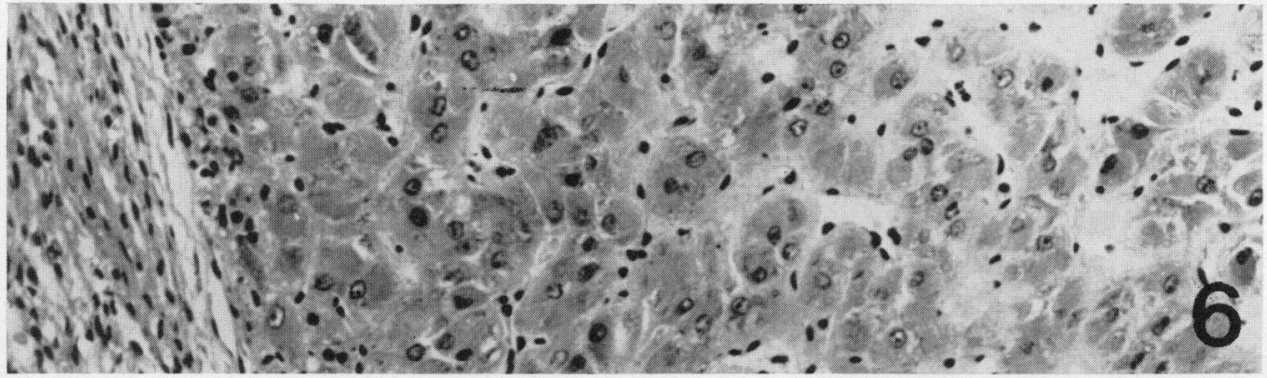

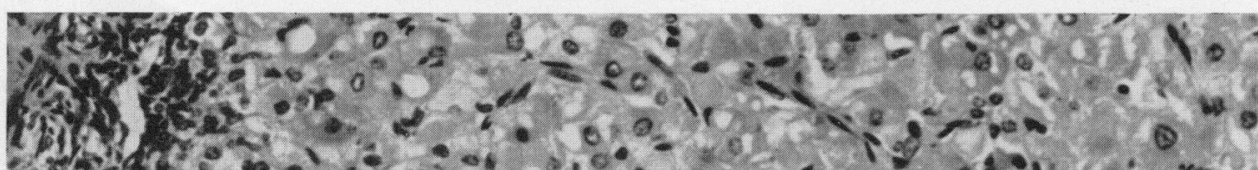
7.

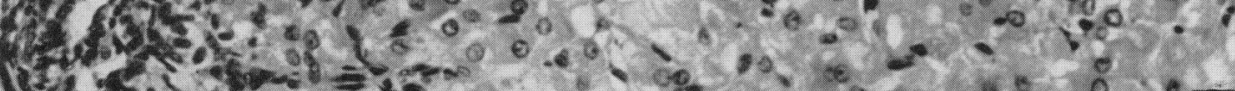

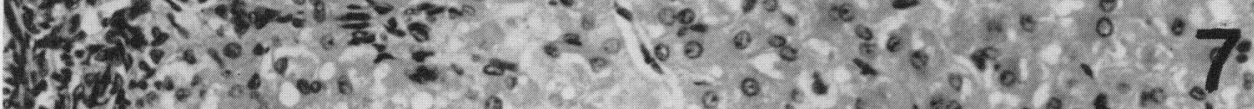

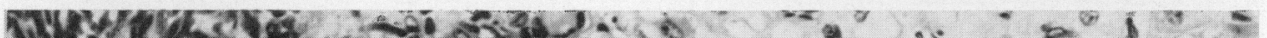

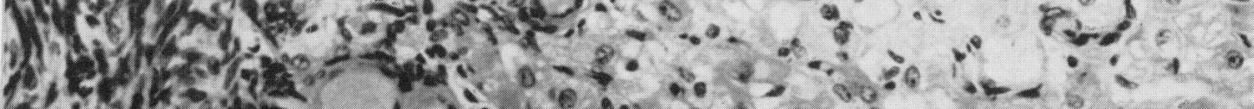

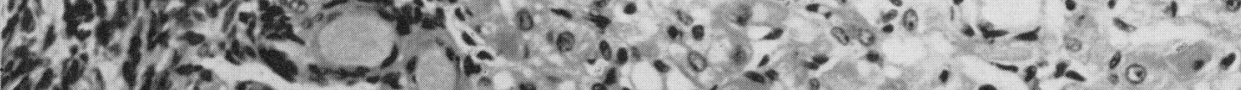

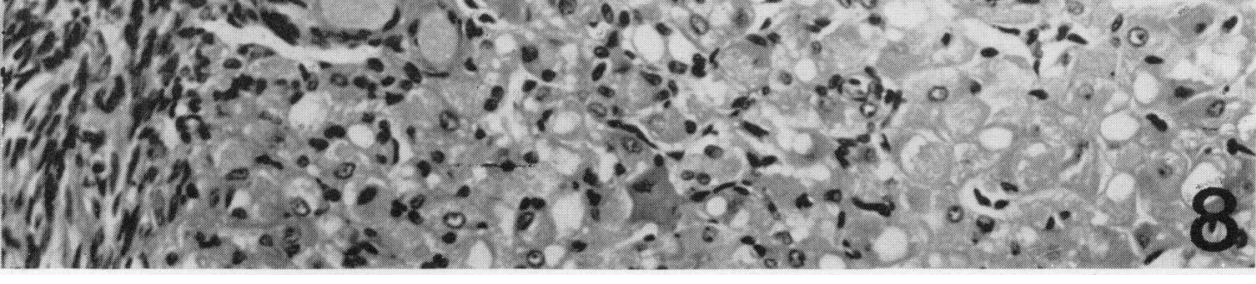




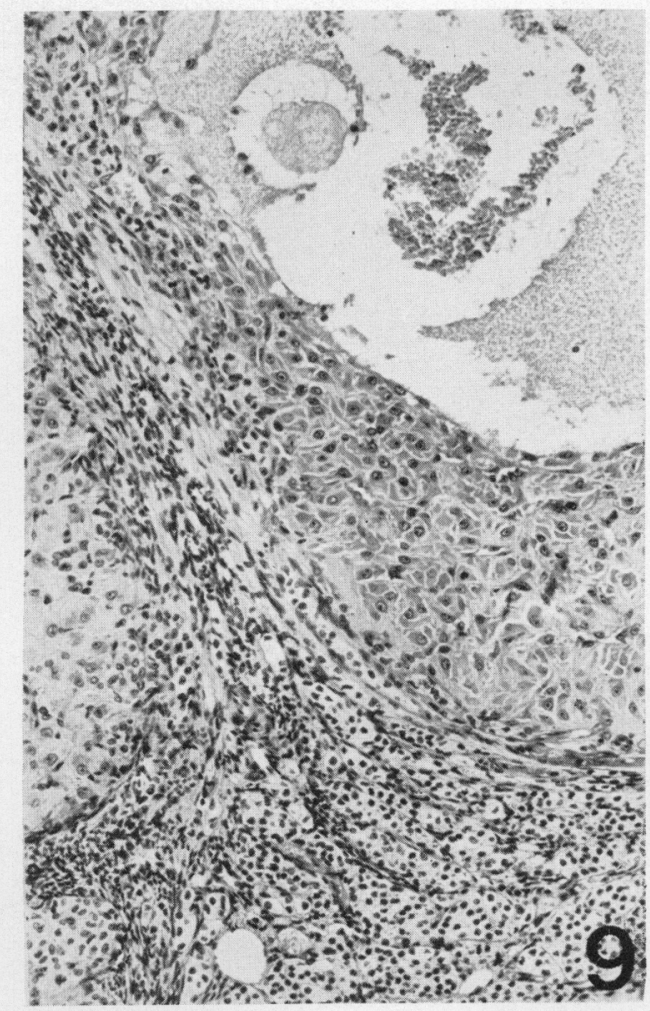

(1) H

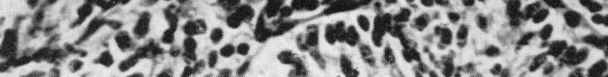
a.m. s.r.t. 1. 3 . .

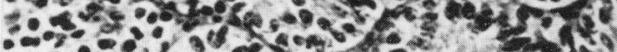

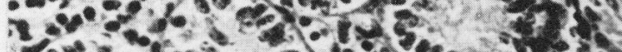

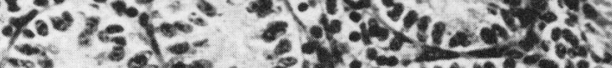
iv of

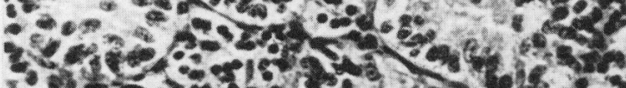
i.

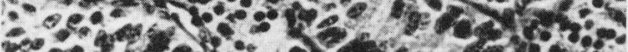
Fes.

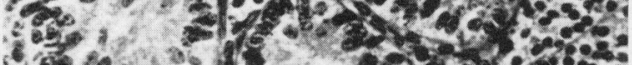

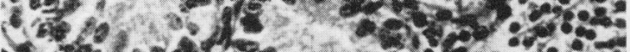

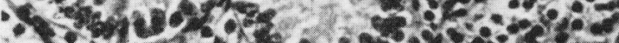

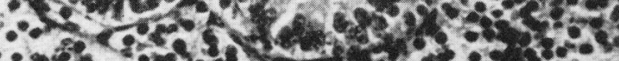

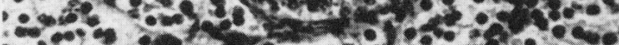

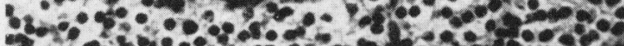

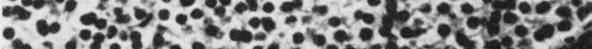

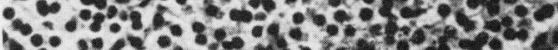

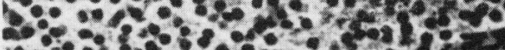

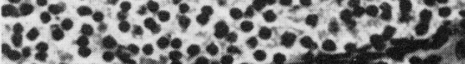
is.

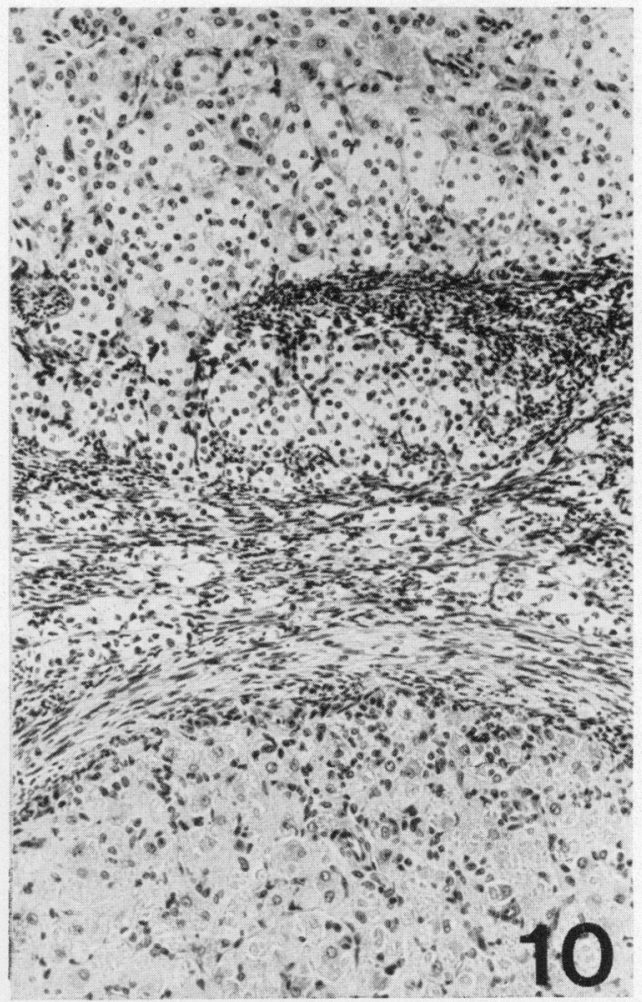

-

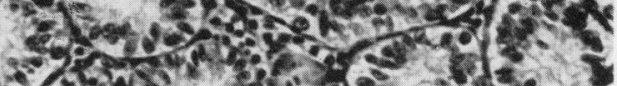

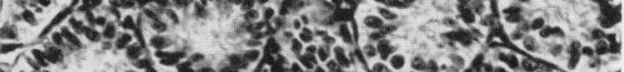

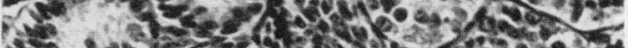

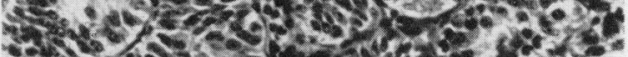

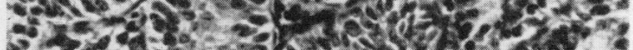

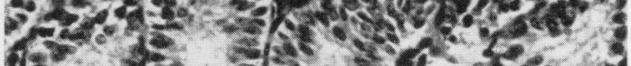

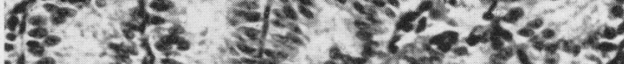

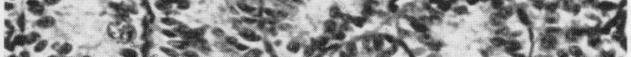

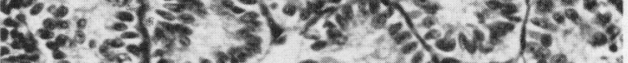

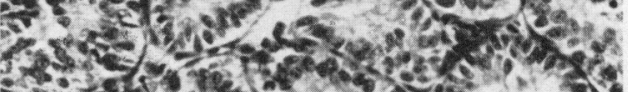
205302 . 5828 . 35 \%

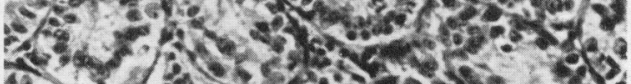
a. 

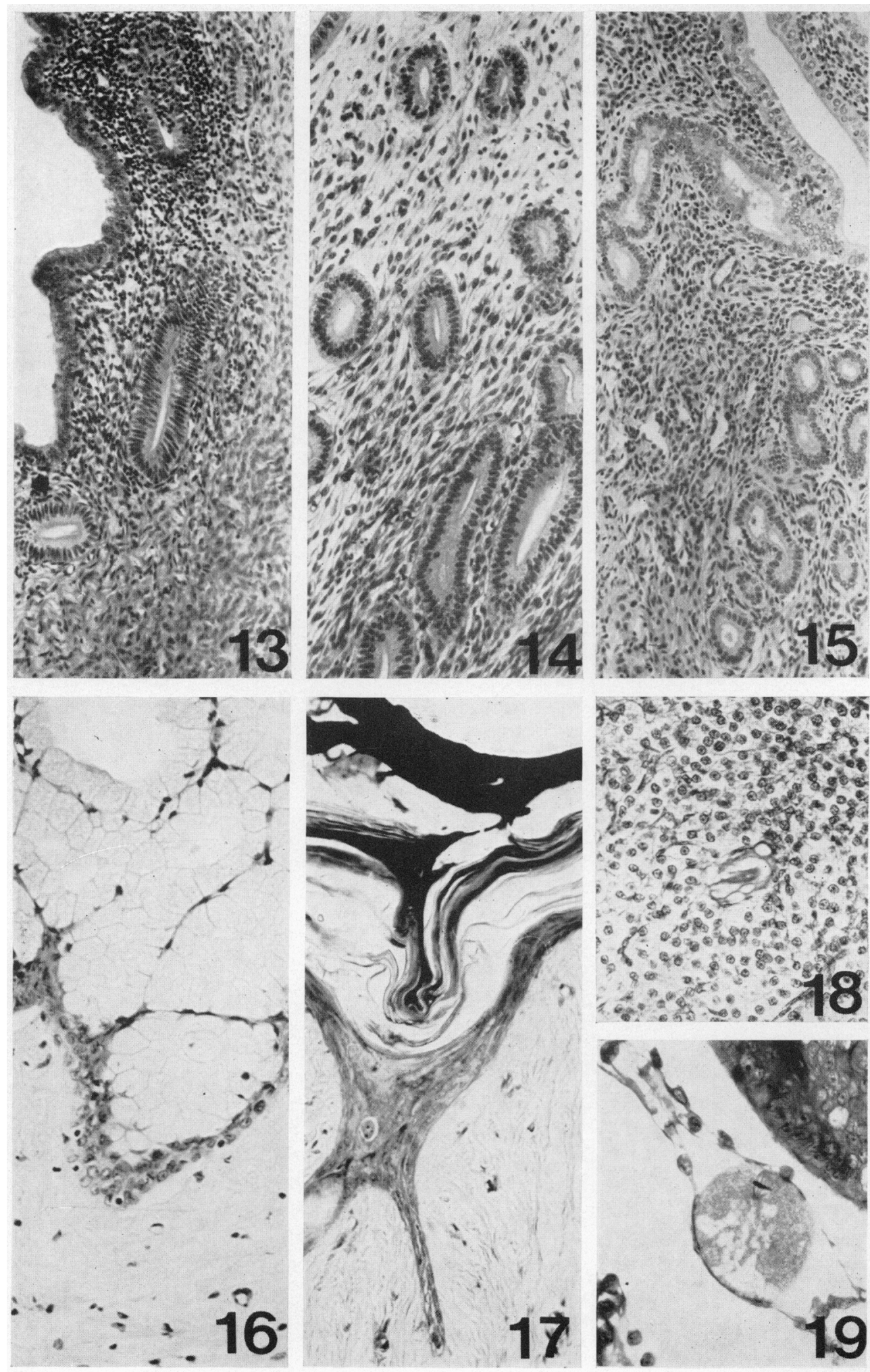

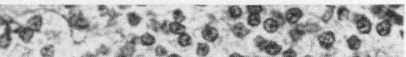
$405000 \%$

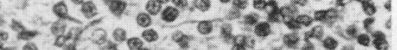

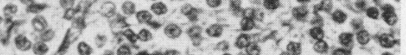
40.070 .

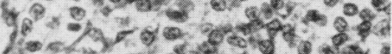

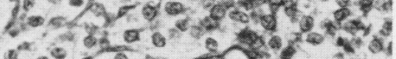

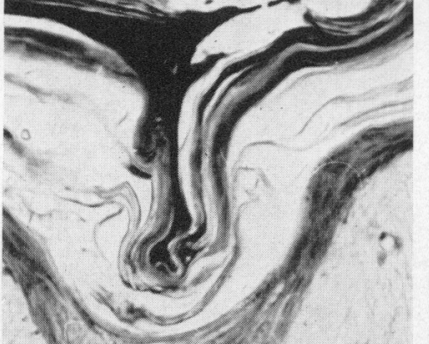

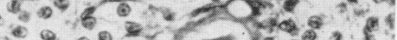
- a.92-2 fo $20 \% 30.420602$

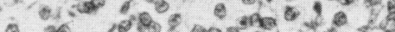

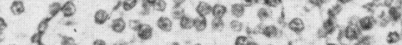
$6 \% 90=80 \% 50604$

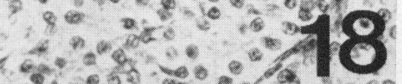
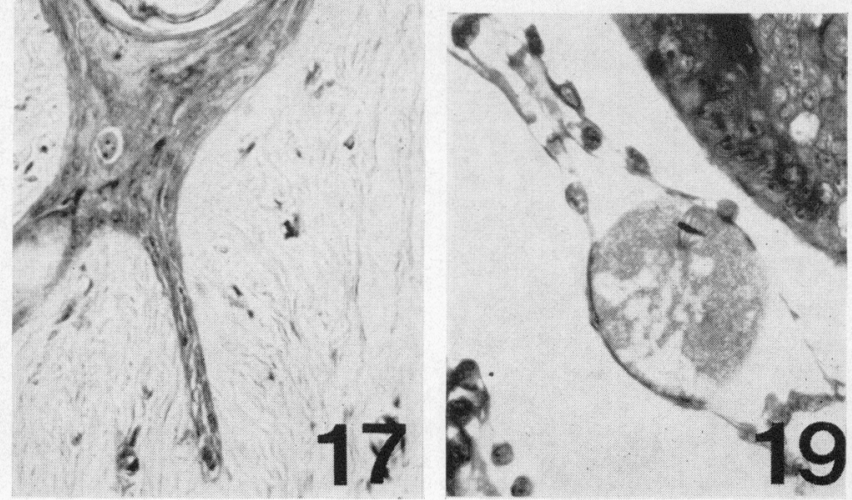
diameter (Pl. 1, Fig. 3). Although this may be the ovulatory size of the follicle in this species, it seems probable, from the sizes of CL of ovulation, that a rapid growth phase occurs just before ovulation. Thus, the ripe Graafian follicle in this species may be about $1000 \mu$ in diameter. The number of follicles ovulating appears to be from one to five. The agouti (D 9) treated with PMSG and HCG ovulated two ova from the left ovary and three from the right (P1. 4, Fig. 19). The agouti follicle is surrounded by two thecal cell types, but typical theca externa cells are more predominant than theca interna cells (Pl. 1, Fig. 3; Pl. 3, Fig. 9). The latter are often not organized into a thecal layer, but exist as scattered cells in the theca externa which is usually 50 to $100 \mu$ in thickness. Transformation of follicles into accessory CL by luteinization (Pl. 3, Fig. 9), or into interstitial tissue (Pl. 4, Fig. 18), may take place at all stages in their development.

Corpora lutea. These are developed from ovulated follicles of about $1000 \mu$ in diameter. Stigmata are not usually apparent but the new CL retains a central lumen for a few days. The maximum diameter of the CL of ovulation observed in the cycle and in pregnancy is about $3000 \mu$. Infiltrations of endothelial cells are particularly prominent (Pl. 2, Figs. 4 to 8 ) and central or random lacunae of extravasated blood may be found. In such a small series of animals with different and unknown histories, it is difficult to age the CL according to the known stage of reproduction and diagnosis of age has only been possible within limits based on histological appearance. A selection of cell types seen in agouti cL is shown in Pl. 2, Figs. 4 to 8. Several ovaries contained many large (diameter $2000 \mu$ ) CL of two or three different histological types, and this indicates that the CL of the cycle, at least, are persistent beyond the next ovulation. No trace of a corpus albicans was seen and regression is probably rapid when it begins. The oldest stage of CL formation is possibly that seen in $\mathrm{D} 17$ ( $\mathrm{Pl}$. 2, Fig. 5).

Accessory corpora lutea. These lutein bodies, as in other hystricomorphs, are formed from unovulated follicles (Pl. 3, Fig. 9). Every agouti ovary contained accessory CL (Pl. 1, Figs. 1 and 2) although in some ovaries, they were small $(<400 \mu)$ or few in number. The largest recognizable accessory cL was $800 \mu$ in diameter and this was smaller than any of the presumed true CL. However, since egg or zonal remnants are not commonly found in agouti accessory CL (unlike the acouchi) it is possible that some lutein bodies in the ovary greater than $800 \mu$ in diameter are, in fact, accessory CL. There were fewer accessory CL in the ovaries of animals believed to be pro-oestrous; most were found in those agoutis which were, or had been, pregnant (D 10, D 17, D 18 and D 20). A larger series, especially during pregnancy, would perhaps reveal further growth of accessory CL to the size of true CL, as occurs in chinchilla.

Interstitial tissue. This is the most striking feature of the agouti ovary. With the exception of one animal (D 10), there was little stroma in any ovary and anything which was not follicular or luteal in nature appeared to be interstitial tissue. This tissue is clearly formed from transformation of follicles (Pl. 3, Fig. $10 ;$ Pl. 4, Fig. 18), but the interstitial cells are unlikely to be formed from those of the theca interna since they are so sparse in agoutis. Figure $10(\mathrm{Pl} .3)$ suggests that the membrana granulosa cells may be transformed into either interstitial or luteal tissue. 
'Immature testis tubules'. Tubules resembling immature testis tubules were found in three animals (D 2, D 3 and D 4) and in one of these, patches of tubules (Pl. 3, Fig. 11) were seen in at least nine different sites, including one which was situated in the mesovarium. Part of the testis of an immature male agouti is shown in Pl, 3, Fig. 12 for comparison.

Papilloma. This bilateral structure (Pl. 1, Fig. 2) was found in D 15. The papilloma with its connective tissue core, was derived from the germinal epithelium; one pole of each ovary was affected and the growth occupied 50 to $60 \%$ of the organ. The rest of the ovary was normal in size and appearance for an agouti. In dogs, surface papillomata occur naturally (Gotchin, 1961) and have been induced by stilboestrol treatment (Jabara, 1959).

\section{Uterus}

As in most hystricomorphs so far studied (Weir, 1967b), it was not possible to detect any cycle of changes in the uterus which reflected the ovarian cycle. In most animals, the endometrium was shallow and the glands were sparse (PI. 4, Fig. 13). Increased glandular development was seen in D 8 and D 19 (Pl. 4, Fig. 15), both of which had cornified vaginae. Agouti D 16 showed similar glandular activity and was classified as being post-oestrous, partly because of this character and partly because there were fairly new CL in the ovaries. Glandular development and an unusually thick endometrium were seen in D 3 (Pl. 4, Fig. 14), which also was thought to be post-oestrous. Leucocytic infiltration through the uterine epithelium was observed in most animals.

\section{Vagina}

A clear pattern of change in the vaginal epithelium was seen. In pro-oestrus (Pl. 4, Fig. 16) and pregnancy, extreme mucification occurred, and was sufficient to dilate the vagina to about five times its usual volume. Cornification of the epithelium (Pl. 4, Fig. 17) was seen in two animals (D 8 and D 19) but it is not certain that either of these were actually in oestrus. Agouti D 8 had a new GL in the ovary but had not shown recent vaginal opening. Nothing was known about D 19, but the vagina was closed at autopsy, there were no recent CL and there were no ripe follicles to indicate an incipient ovulation. In D 9, ovulation was induced (Pl. 4, Fig. 20) and the vaginal epithelium was mucified but, since opening of the closure membrane did not occur, it is reasonable to assume that the hormonal regimen was not correctly balanced.

Leucocytes from the vagina and the uterus are a common feature of smears or sections of the vaginal contents of the agouti.

\section{DISCUSSION}

It is possible that agoutis do not reach puberty until they are over 2 years of age. The state of the ovaries and vagina of D 13 indicated that maturity had not been reached, although this female was reported as being $2 \frac{1}{2}$ years old. This is surprising since Roth-Kolar (1957) indicated that agoutis in zoos may conceive at about $5 \frac{1}{2}$ months of age. However, material from two male agoutis, aged 21 and 
$2 \frac{1}{2}$ years (same source as D 13), showed that spermatogenesis had not started (P1. 3, Fig. 12).

Before puberty, many follicles must grow to a certain size and then become transformed into either luteal or interstitial tissue. The lack of differentiation of theca interna tissue is unusual in comparison with most mammals, although Guraya (1968) has reported a similar finding in Didelphis. However, Guraya states that "those ovaries in which the theca interna cells are well differentiated, generally show a greater amount of interstitial gland cells than the other ovaries having a poorly differentiated theca interna". This is a valid general rule for some other hystricomorphs, e.g. Hystrix, Chinchilla (Weir, 1967b) which have a well-developed theca interna and abundant interstitial tissue, but does not appear to apply to the situation found in the agouti.

Once ovulation has occurred, the follicle becomes converted into a $\mathrm{CL}$, which presumably secretes progesterone. Ovulation appears to take place in both ovaries but in the three pregnant and one post-partum agouti in this series, the foetuses were found only in the right horn. The CL of the cycle is almost certainly functional throughout the long cycle of 34 days in the agouti, as has been shown for the guinea-pig (Rowlands \& Short, 1959), chinchilla (Weir, 1967b) and acouchi (Rowlands, Tam \& Kleiman, 1970). However, luteinization of unovulated follicles also occurs, especially during pregnancy, and occurs in large numbers in some animals. These accessory CL may be expected to secrete progesterone and, in the chinchilla, the accessory cL have been shown to contain the necessary $\Delta 5-3 \beta$-hydroxysteroid dehydrogenase activity (Weir, 1967b). In spite of all the luteal tissue in the ovary, investigations on other hystricomorphs (guinea-pig: Rowlands \& Short, 1959; coypu: Rowlands \& Heap, 1966; chinchilla: Weir, 1967b; acouchi: Rowlands et al., 1970) have shown that plasma and luteal progesterone levels are somewhat lower than in other mammals. The agouti probably follows the same pattern but reasons for such low levels, even during pregnancy, are obscure.

In view of the occurrence of an immediate post-partum oestrus and ovulation in some hystricomorphs and its doubtful occurrence in the acouchi, the ovaries of D 18 and D 20 were of interest. In D 20, which had died in dystocia with an oversized foetus in the right horn, there were five CL greater than $2000 \mu$ in diameter in the right ovary and two in the left. All seemed to be of the same histological type (Pl. 3, Fig. 10) and were probably associated with the pregnancy. There were several accessory cL which were completely formed and some follicles were luteinizing. Two such follicles in the left ovary were $1000 \mu$ in diameter which may indicate that a post-partum ovulation could occur in this species, but in D 18, there were only two large CL (Pl. 2, Fig. 4) in the right ovary, two placental sites in the distended right horn and a highly mucified vaginal epithelium. It was concluded that this animal had recently given birth and that the CL were those of the pregnancy. These CL were still large $(3000 \mu$ in diameter) and looked very healthy. There were no new CL of ovulation and it is unlikely that rejuvenation had taken place during a possible post-partum LH surge. The lack of any follicles greater than $700 \mu$ in diameter and a nearly closed vagina would seem to preclude an imminent LH surge in this animal and probably also a post-partum ovulation and oestrus for this species. 
The sporadic occurrence of 'immature testis tubules' has been reported for individuals of several mammalian species (League \& Hartman, 1925; Wilcox \& Mossman, 1945; Clough, 1966), and they have been seen in the chinchilla (Weir, unpublished observations). The finding of such structures in three of fourteen random agoutis, and in the related acouchi (Weir, 1971), might indicate a familial predisposition towards the retention of primitive sex cords. A comparison of Figs. 11 and 12 (Pl. 3) shows that the term 'immature testis tubule' is appropriate.

This study on a small number of animals has shown that, although reproductive patterns and certain anatomical features of the reproductive organs of the agouti can be considered typical of the hystricomorph rodents so far investigated (mountain viscacha: Pearson, 1949; Ganadian porcupine: Mossman \& Judas, 1949; coypu: Rowlands \& Heap, 1966; acouchi: Weir, 1967b; Rowlands et al., 1970; chinchilla: Weir, 1966, 1967b; African porcupine: Weir, 1967b; plains viscacha: Weir, in preparation), the ovarian morphology is characteristically distinct. This species is yet another hystricomorph which emphasizes the fact that within this sub-order of the rodents, intrafamilial differences can be as striking as interfamilial variations.

\section{ACKNOWLEDGMENTS}

This study was supported in part by the Agricultural Research Council and by the Ford Foundation. The photographs were taken on a Zeiss Ultraphot microscope provided by the Wellcome Trust. My thanks are due to Professor Sir Alan Parkes and Dr I. W. Rowlands for their constant help and encouragement, and to the pathologist of the Zoological Society of London, Dr I. F. Keymer, for permission to collect material from post-mortem specimens of agoutis.

Dr E. G. Gotchin kindly diagnosed the papilloma.

\section{REFERENCES}

Asdeli, S. A. (1964) Patterns of mammalian reproduction, 2nd edn. Cornell University Press, Ithaca, New York.

Becher, H. (1921a) Die Entwicklung des Mesoplacentariums und die Placenta bei Aguti (Dasyprocta azarae Schl.). Z. Anat. EntwGesch. 61, 337.

Becher, H. (1921b) Der feinere Bau der reifen Placenta von Aguti (Dasyprocta azarae Schl.). Z. Anat. EntwGesch. 61, 439.

Brown, C. E. (1936) Rearing wild animals in captivity, and gestation periods. 7. Mammal. 17, 10.

Cabrera, A. \& Yepes, J. (1960) Mamiferos Sud Americanos, 2nd edn. Historia Natural Ediar, Buenos Aires.

Glough, G. (1966) Reproduction in the hippopotamus. Ph.D. thesis, University of Cambridge.

Cotchin, E. (1961) Canine ovarian neoplasms. Res. vet. Sci. 2, 133.

Crandall, L. S. (1944) Two young agoutis. Anim. Kingd. 47, 125.

ENDERs, R. K. (1931) Parturition in the agouti with notes on several pregnant uteri. 7. Mammal. 12,390 .

GURAYA, S. S. (1968) A comparative histochemical study of the theca interna in the mammalian ovary. Acta morph. neerl.-scand. 7, 51 .

Jabara, A. G. (1959) Canine ovarian tumours following stilboestrol administration. Aust. F. exp. Biol. med. Sci. 37, 549.

League, B. \& Hartmann, G. G. (1925) Anovular Graafian follicles in mammalian ovaries. Anat. Rec. 30, 1 .

Lemmon, F. R. \& WeIr, B.J. (1968) A method for handling agoutis and acouchis. 7. Inst. Anim. Techns, $19(2), 49$. 
Marshall, F. H. A. (1952-66) Physiology of reproduction, 3rd edn. Ed. A. S. Parkes. Longmans, London.

Mossman, H. W. \& Judas, I. (1949) Accessory corpora lutea, luteal cell origin, and the ovarian cycle in the Canadian porcupine. Am. F. Anat. 85, 1.

Newson, R. M. (1966) Reproduction in the feral coypu (Myocastor coypus). Symp. zool. Soc. Lond. 15, 323.

Pearson, O. P. (1949) Reproduction of a South American rodent, the mountain viscacha. Am. F. Anat. 84, 143.

Rood, J. P. \& WeIR, B. J. (1970) Reproduction in female wild guinea-pig. J. Reprod. Fert. 23, 393.

Roth-Kolar, H. (1957) Beiträge zu Aktionssystem des Aguti (Dasyprocta aguti aguti L.). Z. Tierpsychol. 14,362 .

RowLANDS, I. W. \& HEAP, R. B. (1966) Histological observations on the ovary and progesterone levels in the coypu (Myocastor coypus). Symp. zool. Soc. Lond. 15, 335.

Rowlands, I. W. \& SHORT, R. V. (1959) The progesterone content of the guinea-pig corpus luteum during the reproductive cycle and after hysterectomy. F. Endocr. 19, 81 .

Rowlands, I. W., Tam, W. H. \& Kleiman, D. G. (1970) Histological and biochemical studies on the ovary and progesterone levels in the systemic blood of the green acouchi (Myoprocta pratti). 7. Reprod. Fert. 22, 533.

Strahl, H. (1905) Eine Placenta mit einem Mesoplacentarium. Anat. Anz. 26, 524.

WEIR, B. J. (1966) Aspects of reproduction in chinchilla. F. Reprod. Fert. 12, 410.

WEIR, B. J. (1967a) The care and management of laboratory hystricomorph rodents. Lab. Anim. 1, 95.

WeIR, B. J. (1967b) Aspects of reproduction in some hystricomorph rodents. Ph.D. thesis, University of Cambridge.

WEIR, B. J. (1971) Some observations on reproduction in the female green acouchi, Myoprocta pratti. 7. Reprod. Fert. 24, 193.

WrLcox, D. E. \& Mossman, H. W. (1945) The common occurrence of 'testis' cords in the ovaries of a shrew (Sorex vagrans, Baird). Anat. Rec. 92, 183. 